\title{
Food security, sweet potato production, and proximity to markets in northern Ghana
}

\begin{abstract}
Leland Glenna $^{a \star}$, Yetkin Borlu ${ }^{b}$, Thomas Gill ${ }^{c}$, Janelle Larson ${ }^{d}$, Vincent Ricciardi ${ }^{e}$, and Rahma Adam ${ }^{f}$
a Agricultural Economics, Sociology, and Education Department, The Pennsylvania State University, 114 Armsby, University Park, PA 16802, USA; ${ }^{b}$ Department of Sociology \& Anthropology, University of Richmond, 302 Weinstein Hall, 28 Westhampton Way, Richmond, VA 23173, USA; 'Smith Center for International Sustainable Agriculture, University of Tennessee Institute of Agriculture, 2640 Morgan Circle Dr., Knoxville, TN 37996, USA; ${ }^{\mathrm{A} A g r i c u l t u r a l ~ E c o n o m i c s, ~ S o c i o l o g y, ~ a n d ~ E d u c a t i o n ~ D e p a r t m e n t, ~}$ The Pennsylvania State University-Berks, Tulpehocken Road, Reading, PA 19601, USA; ${ }^{\mathrm{e} I n s t i t u t e}$ for Resources, Environment, and Sustainability, University of British Columbia, 2329 West Mall, Vancouver, BC V6T 1Z4, Canada; ${ }^{\mathrm{f}}$ International Maize and Wheat Improvement Center (CIMMYT), c/o The World Agroforestry Center, ICRAF House, United Nations Avenue, Gigiri, P.O. Box 1041, Nairobi 0062, Kenya

*LLG13@psu.edu
\end{abstract}

\section{Abstract}

Debates concerning how to achieve food security tend to fall into one of two camps. The first is that high-technology, market-oriented approaches promise to enhance agricultural productivity and improve food security. The counterargument is that low-technology approaches, when combined with building social and physical infrastructure, are more effective at meeting people's food needs. Using a survey of 540 farm households in northern Ghana, we assess the level of food security for smallholders by analyzing the influence of a low-technology and low-external-input approach, such as sweet potatoes, and that of the production of an improved, commercially produced crop, such as rice. We also measure the influence of market access. Our results indicate that sweet potato producers are more likely to be food secure than commercial rice producers. However, the proximity to and interaction with markets is also associated with farmer food security, even when controlling for measures of prosperity. These findings suggest that low-technology approaches and high-technology, market-oriented approaches should not be treated as diametrically opposed to each other. Enhancing smallholder production of low-technology staple crops like sweet potatoes is likely to improve well-being. At the same time, interventions to build the physical and social infrastructure necessary to enable market participation would also be likely to enhance smallholder well-being.

Key words: privatization, agricultural development, social and physical infrastructure, markets

\section{Introduction}

The debate over how to address global food insecurity can be reduced to two competing perspectives. One favors the privatization of government services, high technology, standardized ecosystem services, and commercial production for global markets as the most effective and efficient approach to achieving food security. The other emphasizes working with natural processes, local sourcing, community building, and meeting human needs directly through enhanced subsistence production, as opposed to market mechanisms (Stokstad 2008). 
The emphasis on privatizing government services and market-based approaches gained official support from the World Bank in 1981, when the Berg Report recommended downsizing government support for agricultural production around the world because the private sector and markets were thought to be more efficient and effective at meeting people's needs (Berg et al. 1981). The emphasis on high technology came later, but it has become a key feature in the argument for more privatization and markets. Today, agribusiness firms, many agricultural science and technology proponents in general, and many philanthropic organizations tend to promote market-based, high-technology solutions (Glenna et al. 2015). High-technology solutions refer to mechanization, commercialized inputs, and genetically improved crops and livestock. The Bill and Melinda Gates Foundation offers a rationale for this perspective: improved technology will "boost the yields and incomes of small farmers in Africa and other parts of the developing world so that they can lift themselves and their families out of hunger and poverty". ${ }^{1}$ This rationale is also prominent in global agricultural research organizations. For example, a 2005 Consultative Group for International Agricultural Research (CGIAR) Consortium report stated that for small farmers, the "chances of rising out of poverty depend directly on their ability to increase the productivity of their crop and livestock husbandry activities" (quoted in Harris and Orr 2014, p. 84). The underlying assumption is that technologies can boost yields, which farmers can then sell for profit, thus relieving their households of both poverty and hunger.

Others counter that the high-technology, market-oriented approaches are ineffective, and even counterproductive, for achieving food security and poverty reduction. They contend that these high-technology approaches represent a diversion of resources and attention from well-known existing approaches to enhancing food security, such as improving subsistence farming and other interventions that consider the appropriateness to the local context (Mazoyer and Roudart 2006; Moseley et al. 2010; De Schutter and Vanloqueren 2011; Nyantakyi-Frimpong and Bezner Kerr 2015). Meanwhile, examples of low-technology approaches that consider the local context include the use of integrated pest management (van den Berg and Jiggins 2007) and conservation agriculture (Fowler and Rockstrom 2001).

Harris and Orr (2014) challenged the direct link between higher yields and poverty alleviation when they demonstrated that even if new technologies enhance yields, most smallholders simply do not have enough land to produce the volume of commodities necessary to escape poverty. They noted that enhanced production could improve subsistence food provisioning, but that would not necessarily alleviate poverty (Harris and Orr 2014). van der Ploeg (2014) went further when he stated that focusing on subsistent and petty-commodity agricultural production, and not on expanding production for global markets, is the best way to meet peasant livelihood needs while also meeting global food needs. These arguments are consistent with the statement from the International Assessment of Agricultural Knowledge, Science, and Technology for Development (IAASTD) that food security would be best achieved through the extension of agro-ecological knowledge and other low-technology approaches to improving subsistence production among smallholder producers (IAASTD 2009; Vanloqueren and Baret 2009).

We tested these competing approaches to meeting the food needs in developing nations by analyzing a survey of 540 smallholder households in 60 villages in northern Ghana. We conducted the survey as part of a USAID-sponsored research project to understand the sweet potato value chain and to identify potential strategies to strengthen smallholder engagement in this value chain. In addition to questions about sweet potato production, we inquired about household food security, types of crops produced, different production strategies, access to roads and markets, and demographics. The 1gatesfoundation.org/Media-Center/Press-Releases/2008/01/\$306-Million-Commitment-to-Agricultural-
Development. 
resulting data enabled us to test whether producing a low-technology subsistence crop such as sweet potatoes is more conducive to food security than producing commercial crops, while controlling for farm size, wage labor, and other variables. We also analyzed the influence of access and proximity to markets on food security.

\section{Competing perspectives on agricultural development}

The debate between those advocating for market-oriented commercial crops and those promoting low-external-input subsistence production to address food insecurity needs to be considered in the context of earlier debates over the effectiveness of agricultural development. Wright (2012, p. 1716) characterized publicly funded, large-scale efforts to increase food production, such as the creation of university-based agricultural research organizations in the United States and the Green Revolution, as "grand missions of agricultural innovation". Such grand missions, often initiated by what Kydd (2009, p. 431) described as the "developmental state", include the active intervention of a government or governments to provide for basic services and infrastructure, to facilitate production, to enable market functioning, and to ensure private firms that their investments are secure. Following this developmental-state approach, the World Bank encouraged governments to invest in infrastructure during the 1950s, in education in the 1960s, and in enhancing basic living conditions in the 1970s (Peet and Hartwick 2015).

The rationale for such state-driven efforts to promote development was undermined by the publication of the World Bank's Accelerated Development in Sub-Saharan Africa: An Agenda for Action, also known as the Berg Report, which warned of an impending economic crisis in Africa. It blamed that impending crisis on domestic policies in African nations (Berg et al. 1981). The World Bank and the International Monetary Fund then began implementing what became known as structural adjustment approaches to development, pressuring developing nations to adopt austerity measures (Peet and Hartwick 2015). For example, receiving loans was made conditional on reducing public expenditures, privatizing state services, devaluing currency, and enhancing connections to global markets (Woods 2006; McMichael 2008).

Although proponents of these market-oriented approaches to development claimed that they would enhance social well-being, research indicates that such approaches in agricultural development efforts actually reduce food security, food quality, and smallholder resilience. For example, Isaacs et al. (2016) found that a policy change in Rwanda to intensify commercial crop production reduced traditional cropping systems, which also led to a reduction in yield, market value, nutritional quality, and landuse efficiency. Although this Rwanda study is not directly linked to the World Bank structural adjustment policy, it demonstrates how a narrow emphasis on marketization and intensification can have detrimental impacts.

Even the World Bank has conceded that structural adjustment has been a failure. An independent evaluation commissioned by the World Bank concluded that "the agriculture sector has been neglected by both governments and the donor community, including the World Bank" (Independent Evaluation Group 2007, p. xxiii). This has left people wondering what will replace the emphasis on markets and privatization (Peet and Hartwick 2015). It is in this context that the debate unfolds over whether low-external-input and low-technology approaches to agricultural development are better than high-technology, market-driven approaches.

It is important to recognize that the emphasis on market-oriented efforts to increase agricultural production, reduce food insecurity, and reduce poverty has not disappeared at the World Bank or at the United States Agency for International Development (Woods 2006; USAID 2009). There has been a rhetorical shift to emphasizing political institutional reforms so that markets will function properly, 
but the focus remains on market-oriented development (Peet and Hartwick 2015). Large-scale philanthropic projects, such as those initiated by the Gates Foundation, still emphasize a market-oriented approach, even if less extreme than the structural adjustment approach of the 1980s and 1990s (Stubbs 2003; Kaufman 2009). The emphasis on market-oriented development persists (Harris and Orr 2014).

It is important to distinguish between global and local market-oriented approaches to development. Many economists criticize ideological commitments to global trade liberalization and assert that state-driven development is needed (Krugman 2007; Chang 2008; Galbraith 2008). However, they do not deny the importance of market exchange for human well-being. Focusing specifically on eastern and southern Africa, Barrett (2008) argued that macro-economic policy approaches, such as global trade liberalization, are simply not as effective at improving staple food production among smallholders as facilitating the creation of organizations, reducing the costs of intermarket commerce, improving access to useful on-farm technologies, and stimulating local market participation.

Sociologists have staked out an even stronger position against the global trade liberalization position. For example, van der Ploeg (2014) argued that greater reliance on global markets makes farmers more vulnerable to economic shocks and, therefore, less likely to contribute to food security or to poverty reduction. Although this might seem extreme at first glance, he points to empirical research, especially on smallholder production in China, to make his case. Highlighting this research, he notes that, when small farmers are able to maintain some autonomy by being grounded in their local social and ecological contexts, they are able "to produce for markets without being completely dependent on markets" (van der Ploeg 2014, p. 1010).

This wariness towards market-oriented development, in general, provides the foundation for claims that low-technology and low-external-input approaches would be more effective than agricultural industrialization and privatization (see Pretty 1997; Moseley et al. 2010; De Schutter and Vanloqueren 2011; Nyantakyi-Frimpong and Bezner Kerr 2015). Research does provide some support for this approach. Tripp (2006) analyzed what he refers to as low-external-input agricultural development. Because many high-technology approaches to agricultural development have included the use of external inputs, lowtechnology and low-external-input agriculture overlap. Focusing only on a specific set of crop management practices in a series of case studies, Tripp (2006) concluded that, the low-external-input approach offers limited success. Despite some examples of success (e.g., Franzel et al. 2002; Winarto 2004), farmers require additional skills or resources to implement the low-technology and low-input practices (Graves et al. 2004; Tripp 2006). Tripp (2006) argues that the point is not to find a successful example and then scale up, but rather to better understand what kind of educational, extension, and farmer organizations would be necessary to enable any resource-poor, smallholder farmers to take advantage of crop management practices and technologies. Pretty (1997) has noted that, without investments in organizational and skills development, the farmers with more resources are still going to benefit disproportionately over poorer farmers. These critical assessments highlight the need to focus on human capacity development and physical infrastructural factors that influence well-being, regardless of the intervention being a low-technology or high-technology approach.

A more nuanced perspective on markets is also needed. In fact, scholars offering harsh critiques of the excessive emphasis on high-technology, global market-oriented approaches to development do not necessarily deny a role for markets in promoting development.

de Janvy et al. (1991, p. 1401) asserted that "a market fails when the cost of a transaction through market exchange creates disutility greater than the utility gain that it produces, with the result that the market is not used for the transaction". de Janvy et al. (1991) and Goetz (1992) clarified that if some institution does not intervene to correct for that imbalance, the transaction will not take place. 
de Janvy et al. (1991) bluntly claimed that the nonexistence of markets is an extreme example of market failure.

The state is an example of an institution that can intervene to provide the social and physical infrastructure necessary for markets to exist and to function. However, not all states are equally endowed or competent. Bromley and Anderson (2012) distinguished between a notional state and a coherent state. A notional state is a state in name only because there is no collective memory, no favorable institutional context, no physical infrastructure to facilitate access to markets, and no social infrastructure to enable governance. A coherent state, by contrast, has some sense of shared history among its people, clearly defined land, capital, and labor markets, and a state infrastructure that allows for tax collection, policy implementation, and a police force. Furthermore, state infrastructure would be necessary to build physical infrastructure. Bromley and Anderson (2012) also noted that many developing nations may have elements of a coherent state in their cities, but that those same nations may lack a state infrastructure in the countryside. They further argued that autarky is most likely to exist in the absence of a coherent state.

The implication of this perspective is that a market's emergence and sustenance are contingent on social and physical infrastructure. People may need to trade goods and services to thrive, but without basic institutions and infrastructure to connect them, people will remain isolated. This indeed was the basic understanding that drove agricultural development in the United States during first half of the 20th century. Galpin (1918) documented the presence of trade centers and how people's proximity to trade centers often corresponded with their overall well-being. He further sought to understand "how to erect and maintain local rural institutions which will adequately reinforce" particularly beneficial characteristics of the farmer class (Galpin 1918, p. 57). His stated goal was to foster more interaction between farmers and others through the development of more trade centers.

It is widely recognized that the necessary infrastructure to enable market interactions is lacking in sub-Saharan Africa. Smale et al. (2011, p. 3) reported that "Only a quarter of farmers in subSaharan Africa live within 2 hours of markets by motorized transport .... An estimated $75 \%$ of farmers are located more than 4 hours from the nearest market". It is difficult to imagine how markets can be a solution to the problem of food insecurity when people lack access to markets.

When Bromley and Anderson (2012), Wiggins (2000), and Galpin (1918) advocated for more markets, they were not driven by an ideological agenda to eliminate government services. Rather, according to their perspective, functioning markets facilitate social interaction. Furthermore, smallholder farmers who lack access to markets would be more likely to be poor and food insecure because they are isolated and excluded, not because markets have some metaphysical capacity to end poverty.

The point of this literature review is to highlight the need to look critically at competing arguments for promoting agricultural development. Although the market-oriented approach of the 1980s and 1990s was a failure, there is evidence that becoming more socially integrated through market interactions could enhance smallholder well-being. At the same time, however, we want to test the counterargument, which is that focusing on subsistence crop developments for smallholders might reduce food insecurity more than focusing on higher technology, commercial crop development.

\section{Data and methods of analysis}

After completing the institutional review board process at the Pennsylvania State University to conduct research involving human subjects, we collaborated with the Savannah Agricultural Research Institute (SARI) to conduct a survey of 540 households in three regions of northern Ghana. We purposively selected four districts in the Northern Region, three in the Upper East Region, and three in 
Table 1. Survey sampling frame.

\begin{tabular}{lccc} 
Regions & No. of districts & $\begin{array}{c}\text { No. of communities } \\
\text { (six per district) }\end{array}$ & $\begin{array}{c}\text { No. of households } \\
\text { (nine per community) }\end{array}$ \\
\hline Northern Region & 4 & 24 & 216 \\
Upper East & 3 & 18 & 162 \\
\hline Upper West & 3 & 18 & 162 \\
Total & 10 & 60 & 540 \\
\hline
\end{tabular}

the Upper West Region. As the project was funded by USAID to better understand sweet potato value chains in northern Ghana, we purposively sampled districts within the regions that were likely to produce sweet potatoes. We then purposively sampled six villages within each district that were likely to be growing sweet potatoes. The total number of villages selected was 60 . This technique ensured that the sweet potato communities were evenly distributed within the districts. Once we had selected the six villages in each district, we randomly selected nine households in 44 out of 60 villages to participate in the survey. The number of respondents randomly selected in the remaining 16 villages varied between five and $12 .^{2}$ Our sampling frame is documented in Table 1.

As the household served as the unit of analysis, we sought to survey the head of the household. The respondents indicated that 518 of the 540 households responding were headed by males, 16 were headed by females, and six of the cases did not have an answer for this question. Because we realized that the heads of households would not always be present, we advised enumerators to interview another member of the household if the head was absent. Of the 540 surveys completed, 476 were done by the head of the household. Although research demonstrates that gender is an important factor in intra-household decisions related to market participation and food security (Riisgaard et al. 2010), we were unable to do a gender analysis with our data because so few women responded to our survey. In Ghana, sweet potatoes are often cultivated by men in rain-fed conditions and at a small scale (FAO 2006). Therefore, it is not a surprise that men were more likely to be the respondents in this survey.

SARI enumerators who spoke the local languages conducted the survey between 7 May 2013 and 24 June 2013. The survey took $2-3 \mathrm{~h}$ to complete as it covered a range of topics, including questions about food security, participation in government programs and farm organizations, crop production, and market participation. The field implementation team numbered up to 24 persons including 16 enumerators, three supervisors, and five data entry clerks. After completing the survey, the enumerators entered the data into an Excel spreadsheet.

To analyze the data, we used a multilevel logistic regression model with binomial distribution to control for dependency. Dependency can be a problem when using purposive sampling of multiple clusters at the village level. Using a two-level model (village level and household level) helps to account for the variation in the dependent variable that generalized linear models cannot control for, due to the dependency at the group level (Raudenbush and Bryk 2002). In our study, the village is the group level. Because of this approach, we obtain more conservative results when measuring relationships between our indicators.

Specifically, we control for the group means of continuous variables at the village level to separate group-level effects from individual-level effects by using random-intercept regression. In this

\footnotetext{
${ }^{2}$ To address the differences in the numbers of respondents in villages, we use a multilevel regression model (discussed below).
} 
approach, only the intercept is included as a random effect (Raudenbush and Bryk 2002, pp. 111-113). Our goal is to get a more precise explanation for associations among independent variables emerging from village-level factors and household-level factors. Had we found statistically significant and theoretically relevant cross-level interactions, we would have included the variable interactions as random effects. Here, we separately explain equations for models at the first level (household) and at the second level (village).

\section{Household-level model (eq. (1))}

The log of the odds of food security for a household is represented by the symbol $\varphi . P$ stands for the probability of food security. $\beta$ stands for the coefficients of intercept and independent variables at the first level. The subscript $k$ indicates the last independent variable. The subscript $i$ represents the cases at the lowest level (i.e., households). The subscript $j$ represents the group the household is located in at the second level (i.e., the village level in our models). As we are using a multilevel logistic regression model there is no error term.

Equation (1): Household-level model for the log odds of food security

$$
\varphi_{i j}=\log \left(\frac{P}{1-P}\right)=\beta_{0 j}+\beta_{1 j} X_{1 i j}+\beta_{2 j} X_{2 i j}+\ldots+\beta_{k j} X_{k i j}
$$

\section{Village-level model (eq. (2))}

The village mean distance to the closest markets is the only second-level independent variable in our models. As we have not detected statistically significant and theoretically valuable cross-level interactions, we are including only the intercept as random effect. Here, the coefficient of the intercept as random effect at the first level is the function of the intercept at the second level $\left(\gamma_{00}\right)$, the coefficient $\left(\gamma_{01}\right)$ of the second level independent variable $\left(W_{j}\right)$, and the random variance component at the second level $\left(u_{o j}\right)$. We include all first-level independent variables as fixed effects.

Equation (2): Village-level model for the log odds of food security

$$
\begin{aligned}
& \beta_{0 j}=\gamma_{00}+\gamma_{01} W_{j}+u_{0 j} \\
& \beta_{1 j}=\gamma_{10} \\
& \beta_{2 j}=\gamma_{20} \\
& \cdots \\
& \beta_{k j}=\gamma_{k 0}
\end{aligned}
$$

\section{Analysis}

We developed three hypotheses related to the influence of technologies and markets on human wellbeing. We used food security as an indicator of well-being. As noted above, we asked on the survey whether respondents had fewer than two meals per day during any of the previous 12 months. If respondents indicated that they had fewer than two meals per day during any month, we coded their households as food insecure. All others were coded as food secure. Scholars have not yet agreed upon a universally valid measure of food security (Maxwell et al. 1999, 2008). However, when conducting a survey of subsistence farmers in a developing country, it is common to ask about the adequacy of food during months of the year. This helps to capture food shortages that might emerge after food stocks are depleted and before the next harvest (Quaye 2008). One concern in this method is reliability when 
asking respondents to recall back over the period of a year. However, these challenges are common in any survey.

Our measure of food security does not address other important measures of human well-being, such as nutritional quality and dietary diversity. Research indicates that smallholders who produce more diverse crops and who have access to local markets, as opposed to global markets, have better nutritional quality and dietary diversity (Jones et al. 2014; Isaacs et al. 2016). Although these issues are important, we chose this measure of food security to make the analysis more straightforward.

\section{Hypotheses}

Hypothesis \# 1: Smallholder farmers who grow a low-technology crop for subsistence (sweet potatoes) will be more food secure than those who do not.

Rationale: Sweet potatoes are an appropriate indicator because they are often highlighted as a lowtechnology solution to a variety of food and nutrition challenges in developing nations. Two variables are useful in measuring reliance on sweet potatoes. One is simply to ask if they are sweet potato producers, which is coded as a 1 if the answer is yes. The second variable is based on the respondent's assessment of whether the sweet potato is a reliable crop (on a four-point Likert scale where $1=$ strongly agree and $4=$ strongly disagree). Previous studies show that sweet potatoes are considered a good food security crop in sub-Saharan Africa because they are hardy, they do not require as much labor as some other staple crops, they are easily propagated, they can be grown where and when other crops would not do well, and they often serve as a reserve crop when grain crops fail (Badstue and Adam 2011; Adam 2013; Adam et al. 2015).

Hypothesis \#2: Smallholder farmers who grow a major cash crop (rice) will be more food secure than those who do not grow a major cash crop.

Rationale: Major crops are typically grown on a mass scale for market exchange. Wheat, maize, rice, soya, and cotton are examples. Maize and rice predominate in northern Ghana. Minor crops, such as specialty fruit or nut crops, are typically grown on a smaller scale than major crops. Orphan crops, such as cassava or sweet potato, are likely to be grown by resource-poor, smallholder farmers for subsistence (National Academy of Sciences (NAS) Committee on Genetically Engineered Crops 2016). The distinction between major, minor, and orphan crops is relevant in this paper because private firms and public research organizations direct relatively little time and few resources to study minor or orphan crops (Welsh and Glenna 2006). Therefore, when proponents of high-technology, market-oriented approaches are making their claims, they are nearly always referring to major crops. A relatively new variety of rice, NERICA, is a prominent commercial crop in West Africa. AfricaRice developed an improved rice variety in the early 2000 s and worked with governments and nongovernmental organizations to disperse it widely in West Africa, including northern Ghana (Glenna et al. 2012). Because this rice has been promoted as an improved variety and as a cash crop in northern Ghana, we use the production of rice as an indicator variable for the high-technology, market-oriented crop.

Commercial crop production implies two components. The first is the production of a major cash crop. The second is that the farmer will have the capacity to sell that cash crop in a market. Therefore, we also evaluated market access. We used two indicators of household-level market access and one indicator of village-level access.

Hypothesis \#3: Smallholder farmers who take less time to get to markets and who participate in those markets will be more food secure than those who have less convenient access to markets. 
Rationale: Increased market access would provide more opportunities for smallholders to sell their produce for cash and to purchase foods for their household, thus increasing food security. We used three measures of market access. First, we use the time (in minutes) it takes household members to reach the closest market. We separated this continuous indicator into two different variables: one measures the variation within each village by group-centering at the village level, and the second measures the average amount of time in a village based on the individual responses. By separating the group-level effects from individual variation within a group, we aim to explain whether contextual factors or household-level factors are more influential in determining the level of food security for a household. Focusing on the contextual aspect of connectivity we hope to control for the institutional structure of markets where households exist. The third indicator for access to markets is based on whether households participate in major market centers (on the survey, we referred to them as "bigtown markets"). This provides another way to capture market access, because the size of the market is likely to also be a relevant indicator of well-being. Having a wide array of resources and services, big-town markets are representative of what Galpin (1918) referred to as trade centers that connect rural communities and contribute to their welfare.

To explore social institutional inclusion beyond market access and market participation, we included measures of whether household members are co-operative members or whether they have access to agricultural extension services. Barrett (2008) has linked such farmer organizations with improved household well-being. Furthermore, the existence of producer cooperatives and access to agricultural extension services are indicators of what Bromley and Anderson (2012) called a coherent state, as it reflects a state's institutional capacity to support agricultural production. Access to them would likely enhance human well-being. ${ }^{3}$

To gauge the relative economic status of the households in our sample, we measured the size of landholdings and whether the household hires laborers. We expect that households that can afford to hire a worker would perform better in food security than others. We asked respondents how much farmland they managed to measure landholdings. We recoded a continuous land-size ownership variable into a three-category dummy variable ( $<5$ acres: marginal farmer; 5-10 acres: smallholder; $>10$ acres: medium and large landowners). There is a great variety in how to define a smallholder, including measures of market access or the size of holdings (Chamberlin 2007). As we treat market access as a distinct variable, we use the size of landholding as our smallholder indicator. Using landholding as an indicator of smallholder status can be complicated by land quality and climate conditions. Farmers in some regions of the world would need more land than in other regions of the world to sustain a household (Chamberlin 2007). Because the savanna region of northern Ghana (including the Northern, Upper West, and Upper East regions) has a dry climate and relatively poor soil, landholdings are slightly larger there than in other regions of the country, averaging 4 ha (Chamberlin 2007). Following these insights, we deemed the average of 4 ha to be a good indicator of the average smallholder in the region. Because the enumerators asked about acreage when conducting the survey, we converted hectares into acres for our analysis. As 1 ha is equivalent to 2.47 acres. We defined smallholders as having between five and 10 acres, marginal farmers as having fewer than five acres, and medium- and large-scale farmers as having more than 10 acres. ${ }^{4}$

\footnotetext{
${ }^{3}$ Although Ghana is making efforts to promote private agricultural extension services, nearly all agricultural extension is provided by the government: dev.meas.illinois.edu/wp-content/uploads/2016/07/MEASEVAL-2015-Ghana-ZOI-Moore-et-al-July-2015.pdf.

${ }^{4}$ We merged medium and large landowner categories in our models because we expect any farmers with more than average landholdings to have significantly more food security compared with small and marginal landholders.
} 


\section{Results}

\section{Descriptive results}

\section{Dependent variable}

For our dependent variable, descriptive statistics show that $62 \%$ of our sample reported no food insecurity during any of the previous 12 months (Table 2). This means that over one-third of our respondent households were food insecure at some point during the previous year. According to our data, food insecurity is high between May and August compared with other months, and it is at its highest level in July (Fig. 1).

\section{Independent variables}

Our main independent variables included two approaches to measure sweet potato production: one measure of commercial crop production, and three measures of market access. Just over $90 \%$ of our respondents reported growing sweet potatoes. The mean for those claiming that sweet potatoes are a reliable food source during food shortage was 2.34 (on a four-point Likert scale with 1 being "strongly agree" and 4 being "strongly disagree"). This means that slightly more than half of our

Table 2. Descriptive statistics.

\begin{tabular}{|c|c|c|c|c|c|}
\hline & $N$ & Minimum & Maximum & Mean & Standard deviation \\
\hline $\begin{array}{l}\text { Food security (insecure }=0 \\
\text { secure }=1 \text { ) }\end{array}$ & 529 & 0.00 & 1.00 & 0.62 & 0.48 \\
\hline $\begin{array}{l}\text { Cooperative membership (non- } \\
\text { member }=0 ; \text { member }=1 \text { ) }\end{array}$ & 540 & 0.00 & 1.00 & 0.36 & 0.48 \\
\hline $\begin{array}{l}\text { Access to agricultural extension } \\
(\text { no }=0 \text {; yes }=1)\end{array}$ & 540 & 0.00 & 1.00 & 0.43 & 0.50 \\
\hline $\begin{array}{l}\text { Sweet potato producer }(\text { no }=0 \\
\text { yes }=1 \text {; }\end{array}$ & 514 & 0.00 & 1.00 & 0.914 & 0.28 \\
\hline $\begin{array}{l}\text { Sweet potato reliability (four-point } \\
\text { Likert scale) }\end{array}$ & 525 & 1.00 & 4.00 & 2.34 & 0.80 \\
\hline $\begin{array}{l}\text { Commercial rice grower }(\text { no }=0 \\
\text { yes }=1 \text {; }\end{array}$ & 510 & 0.00 & 1.00 & 0.38 & 0.49 \\
\hline Small farm $(5-10$ acres $=1)$ & 538 & 0.00 & 1.00 & 0.32 & 0.47 \\
\hline $\begin{array}{l}\text { Medium and large farm } \\
(>10 \text { acres }=1)\end{array}$ & 538 & 0.00 & 1.00 & 0.52 & 0.50 \\
\hline Wage labor $($ no $=0$; yes $=1)$ & 540 & 0.00 & 1.00 & 0.73 & 0.45 \\
\hline Distance to market (min) & 520 & 0.00 & 180.00 & 32.87 & 30.32 \\
\hline $\begin{array}{l}\text { Village-level distance to markets } \\
\text { (min) }\end{array}$ & 540 & 2.00 & 73.89 & 32.53 & 14.66 \\
\hline $\begin{array}{l}\text { Access to big-town market } \\
(\text { no }=0 \text {; yes }=1)\end{array}$ & 532 & 0.00 & 1.00 & 0.33 & 0.47 \\
\hline Upper East & 540 & 0.00 & 1.00 & 0.30 & 0.46 \\
\hline Upper West & 540 & 0.00 & 1.00 & 0.30 & 0.46 \\
\hline Valid $N$ (listwise) & 435 & - & - & - & - \\
\hline
\end{tabular}




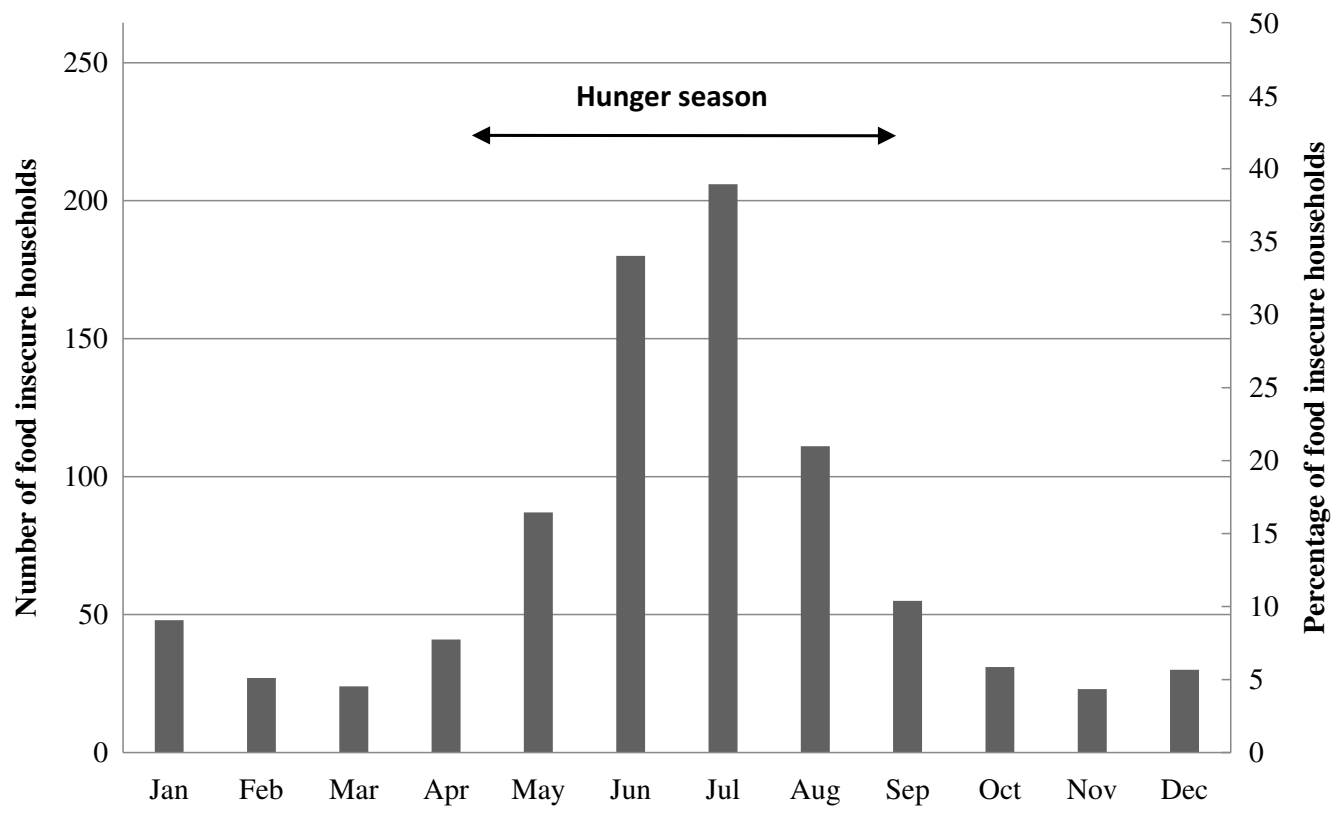

Fig. 1. Annual flux of food insecurity in northern Ghanaian households $(N=529)$.

respondents agree ( $16 \%$ strongly agree and $40 \%$ agree) that sweet potato is a reliable food source during food shortage. Thirty-eight percent of our respondents reported that they sold rice for income. The overall distance to markets varied between 0 and $180 \mathrm{~min}$, with an average of $33 \mathrm{~min}$. However, the village average for distance to closest markets in minutes was significantly different than the distribution, as the maximum distance to closest market at village level was $74 \mathrm{~min}$, which points to significant variation within villages. Therefore, we included the distance to the closest markets as two variables in our statistical models: within-group differences, and village-level averages. Because the distributions of both variables are skewed, we transformed these two continuous variables by natural logarithm in the regression models. Finally, one-third of respondents stated that they go to a major market center to sell their crops.

\section{Control variables}

We asked if any member of the household was a member of a farmer association or group. Thirty-six percent of respondent households had someone in that household who was a cooperative member. Forty-three percent have access to agricultural extension services. As we noted earlier, we consider these variables to be indicators of social engagement and of a coherent state. Seventy-three percent of respondents had hired workers. Approximately one-third of respondent households held 5-10 acres of land, just over half held more than 10 acres, and the rest had fewer than 5 acres.

We also controlled for regional variation as we included two dummy variables for the Upper West and Upper East regions. We set the Northern region as the reference category after we found that it had the lowest score for food security.

\footnotetext{
${ }^{5}$ We found no statistically significant difference in food security among regions in our one-way ANOVA test.
} 
We had some missing cases in our data. However, our analysis did not indicate any systematic biases. To retain all the respondents, we used multiple imputations to replace missing data. We used groups (villages) as a variable in these imputations to account for the multilevel structure of the data.

\section{Analytical results}

Our first logistic regression model assessed whether a multilevel model was required by determining if there was within-group dependency (Table 3). As the intercept value had a significant random effect $(0.559 ; p<0.010)$, we concluded that the differences were significant and needed to be addressed with a multilevel model.

We added indicators that are related to crop production in Model 2. Sweet potato production (3.015; $p<0.000)$ and the belief that sweet potato is a reliable crop during times of food shortage $(0.913$; $p<0.000$ ) were both significantly and positively associated with food security. These findings are somewhat counterintuitive. Sweet potato producers are more likely to be food secure, which offers

Table 3. Binomial logistic regression models explaining food security in northern Ghana.

\begin{tabular}{|c|c|c|c|c|}
\hline Variables & Model 1 & Model 2 & Model 3 & Model 4 \\
\hline \multicolumn{5}{|l|}{ Fixed effects } \\
\hline Intercept & -0.542 & -5.525 & -3.187 & -3.680 \\
\hline Sweet potato producer & - & $3.015^{c}(0.650)$ & $2.710^{c}(0.651)$ & $2.653^{c}(0.658)$ \\
\hline Sweet potato reliability & - & $0.913^{c}(0.146)$ & $0.933^{c}(0.150)$ & $0.934^{c}(0.151)$ \\
\hline Commercial rice & - & $-0.049(0.216)$ & $-0.188(0.221)$ & $-0.268(0.233)$ \\
\hline Distance to markets group-centered & - & - & $-0.114(0.219)$ & $-0.085(0.224)$ \\
\hline Distance to markets group-mean & - & - & $-0.564(0.301)$ & $-0.676^{a}(0.331)$ \\
\hline Access to big-town market & - & - & $0.928^{c}(0.232)$ & $0.936^{c}(0.243)$ \\
\hline Cooperative membership & - & - & - & $-0.138(0.249)$ \\
\hline Access to extension & - & - & - & $-0.007(0.235)$ \\
\hline Small farms & - & - & - & $0.328(0.359)$ \\
\hline Medium and large farms & - & - & - & $0.821^{a}(0.380)$ \\
\hline Wage labor & - & - & - & $0.516^{a}(0.258)$ \\
\hline Upper East region & - & - & - & $-0.037(0.431)$ \\
\hline Upper West region & - & - & - & $0.111(0.392)$ \\
\hline \multicolumn{5}{|l|}{ Random effects } \\
\hline Intercept & $0.559^{b}(0.200)$ & $0.965^{b}(0.305)$ & $0.737^{b}(0.266)$ & $0.677^{a}(0.262)$ \\
\hline AIC & 2362 & 2507 & 2514 & 2531 \\
\hline BIC & 2367 & 2511 & 2518 & 2536 \\
\hline Overall \% correct predicted & 72 & 80 & 78 & 78 \\
\hline
\end{tabular}

Note: Values in parentheses are the standard errors. AIC, Akaike information criterion; BIC, Bayesian information criterion. $(t) p<0.10$.

${ }^{a} p<0.05$.

${ }^{b} p<0.010$.

$c_{p}<0.000$. 
confirmation for hypothesis \#1. However, those who strongly agree or agree that sweet potatoes are a reliable food crop are more likely to be food insecure than those who disagree. However, the reported reliability of sweet potato production should not be understood as a causal factor for food insecurity. Rather, we interpreted it to mean that food insecure households are more likely to think that sweet potatoes are reliable.

Commercial rice production was not statistically significant. This suggests no relationship between the production of a major commercial crop and food security. Therefore, we cannot confirm hypothesis \#2. Glenna et al. (2012) reported that, in northern Ghana, commercial rice production was subsidized and had a guaranteed market for part of the first decade of the 21st century. As that support is no longer in place, the benefits of commercial rice production may have disappeared. There are other possible explanations that our data do not enable us to measure. First, bad weather conditions or other disruptions in a part of northern Ghana could have harmed yields and undermined profitability (Terdoo and Feola 2016). As our survey captured only one season of production, we are unable to control for changes from year to year. Second, Goetz (1992) found that smallholders in sub-Saharan Africa were more likely to participate in markets if they had access to cereal-processing technologies. We did not ask about access to processing technologies in our survey. Third, the smallholders who sold their rice for cash may have spent their income on other needs, such as healthcare or school fees, leaving little or no cash to purchase food when it was needed. Therefore, just because it did not improve food security does not mean that household well-being was not improved.

In the final model (Model 4), we included indicators for access to markets and indicators of prosperity. ${ }^{6}$ Results indicated that the ability to hire farm workers was statistically significant $(p<0.05)$. Longer distances to markets were negatively associated at the individual level (groupcentered), as well as at the village level. However, only the village-level indicator for distance to markets was statistically significant. This finding points to the importance of the household's institutional contexts. Finally, households that have access to major market centers had a significantly higher likelihood of being food secure.

Cooperative membership and access to agricultural extension were not significant. This finding suggests that cooperatives and extension may be inadequately supported in the region, which limits their potential contributions to household well-being. By contrast, the size of farm and the ability to hire wage laborers were both statistically significant (both at $p<0.05$ ), which is consistent with our expectations.

Compared with other categorical variables in this model, sweet potato production and access to a major market center had the largest influences on the likelihood of being food secure. Households with access to major market centers were twice as likely to be food secure as those who do not have access (see Fig. 2). This means that proximity to markets is quite relevant. Even more important, however, is that households growing sweet potatoes were 14 times more likely to be food secure than those who do not grow sweet potatoes. This means that sweet potato production is a very important subsistence crop.

${ }^{6}$ Our final model (Model 4) does not have multicollinearity between independent variables. The multicollinearity condition index for Model 4 was 15. The variable with the highest variance inflation factor was 2.8 .

${ }^{7}$ We ran additional checks on interactions between crop types (commercial rice production and sweet potato production) and our socioeconomic and infrastructure variables (distance to the closest market and access to bigtown markets). These helped us to detect any potential bias due to sampling according to crop type. We also ran interactions between coop membership, access to agricultural extension, and socioeconomic and infrastructure variables (distance to the closest market and access to big-town markets). None of the interactions yielded information that conflicted with the main findings in the final model. 


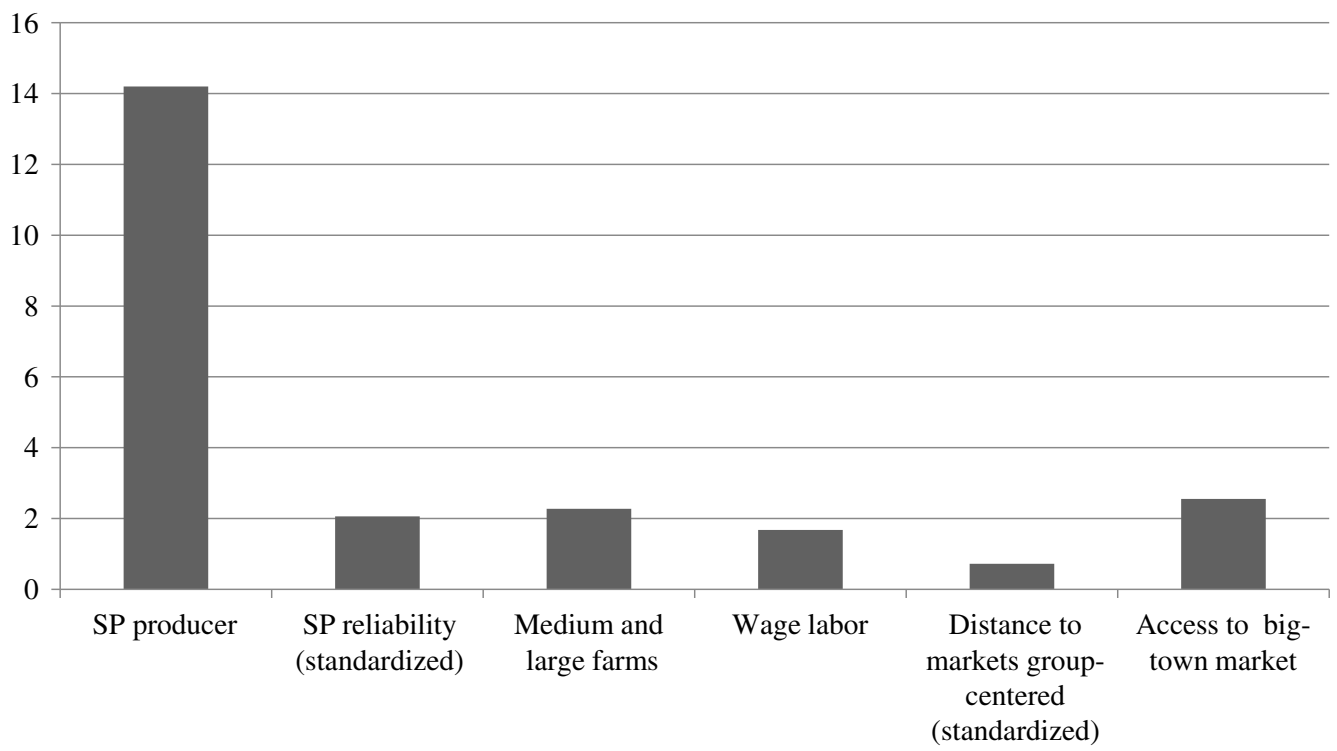

Fig. 2. Odds ratios of the independent variables of food security (Model 4).

\section{Conclusions}

Debates concerning the best strategies for promoting food security in developing nations tend to be framed as competing and irreconcilable approaches. On the one hand, some claim that promoting low-technology staple-food production is the most effective approach. On the other hand, some claim that high-technology, market-oriented approaches are superior strategies for promoting well-being. Our analysis of 540 surveys of mostly smallholder farmers in three northern regions of Ghana suggests that the debate should not be framed as dialectically opposed positions. Rather, smallholder households that produce a low-technology, subsistence crop, like sweet potatoes, are more food secure than those who do not. However, households that have shorter travel times to get to markets and that participate in major market centers are more food secure than those who have farther to travel and who do not participate in larger markets, even when controlling for other variables, such as the size of the operation and connections to services like cooperatives and agricultural extension.

Although our analysis indicates that access to markets is associated with higher levels of food security, our analysis also indicates that commercial commodity production does not increase food security. This is likely because producing a commercial crop does not necessarily mean that a farmer will have access to a market or that a farmer will receive an income adequate to cover the costs of production. By contrast, a low-technology crop, like sweet potato, has a strong and significant relationship with food security because that crop is not contingent on market access.

Because we find that proximity to markets is an important indicator of well-being, it would seem that Galpin (1918) was correct to suggest that public efforts are needed to enhance the social and physical infrastructure needed for people to gain access and to participate in those markets. Therefore, in the absence of efforts to enhance the social and physical infrastructure to build markets, it makes sense to promote low-external-input crops like sweet potatoes because such a crop is likely to improve food security. However, this does not mean that markets might not also aid in improving economic well-being. Rather, it indicates that those markets are unlikely to emerge in the current circumstances. Investment in the development of a coherent state, in the form of physical and social infrastructure necessary to develop functioning markets, may eventually help to integrate otherwise isolated smallholders. 


\section{Acknowledgements}

This research was funded by the United States Agency for International Development HortCRSP program. The Pennsylvania State University and Tuskegee University collaborated on developing the grant proposal and implementing the research project.

\section{Author contributions}

LG, TG, and JL conceived and designed the study. LG, TG, JL, VR, and RA performed the experiments/collected the data. LG, YB, and TG analyzed and interpreted the data. LG, TG, and JL contributed resources. LG, YB, TG, JL, VR, and RA drafted or revised the manuscript.

\section{Competing interests}

LG served as a Guest Editor for this Collection, but was not involved in review or editorial decisions regarding this manuscript.

\section{Data accessibility statement}

All relevant data are within the paper.

\section{References}

Adam RI. 2013. The dynamics and sustainability of production and distribution of sweet potato planting materials among small holder farmers in the Lake Victoria region, Tanzania. Ph.D. dissertation, The Pennsylvania State University, University Park, Pennsylvania. 371 p.

Adam RI, Sindi K, and Badstue L. 2015. Farmers' knowledge, perceptions and management of diseases affecting sweet potatoes in the Lake Victoria Zone region, Tanzania. Crop Protection, 72: 97-107. DOI: 10.1016/j.cropro.2015.02.010

Badstue LB, and Adam R. 2011. Gender and vines: production, management and exchange of sweet potato planting material among smallholders in the Lake Victoria region, Tanzania. Technical paper. International Potato Center (CIP) and Helen Keller International (HKI), Nairobi, Kenya.

Barrett CB. 2008. Smallholder market participation: concepts and evidence from eastern and southern Africa. Food Policy, 33: 299-317. DOI: 10.1016/j.foodpol.2007.10.005

Berg E, Amoako KY, Gusten R, Meerman J, and Tidrick G. 1981. Accelerated development in Sub-Saharan Africa: an agenda for action. World Bank, Washington, D.C.

Bromley DW, and Anderson GD. 2012. Vulnerable people, vulnerable states: redefining the development challenge. Routledge, New York, New York.

Chamberlin J. 2007. Defining smallholder agriculture in Ghana: who are smallholders, what do they do, and how are they linked with markets? International Food Policy Research Institute, Washington, D.C.

Chang H-J. 2008. Bad Samaritans: the myth of free trade and the secret history of capitalism. Bloomsbury Press, New York, New York.

de Janvy A, Fafchamps M, and Sadoulet E. 1991. Peasant household behaviour with missing markets: some paradoxes explained. The Economic Journal, 101: 1400-1417. DOI: 10.2307/2234892

De Schutter O, and Vanloqueren G. 2011. The new green revolution: how twenty-first-century science can feed the world. Solutions, 2(4): 33-44. 
FAO. 2006. The state of food insecurity in the world: eradicating hunger-taking stock ten years after the World Food Summit. Food and Agriculture Organization of the United Nations, Rome, Italy.

Fowler R, and Rockstrom J. 2001. Conservation tillage for sustainable agriculture: an agrarian revolution gathers momentum in Africa. Soil and Tillage Research, 61(1): 93-108. DOI: 10.1016/S0167-1987 (01)00181-7

Franzel S, Phiri D, and Kwesiga FR. 2002. Assessing the adoption potential of improved tree fallows in eastern Zambia. In Trees on the farm: assessing the adoption potential of agroforestry practices in Africa. Edited by S Franzel and SJ Scherr. CABI, Wallingford, UK. pp. 37-64.

Galbraith JK. 2008. The predator state: how conservatives abandoned the free market and why liberals should too. Free Press, New York, New York.

Galpin CJ. 1918. Rural life. The Century Co., New York, New York.

Glenna L, Ader D, Bauchspies W, Traoré A, and Agboh-Noameshie RA. 2012. The efficacy of a program promoting rice self-sufficiency in Ghana during a period of neoliberalism. Rural Sociology, 77(4): 520-546. DOI: $10.1111 / j .1549-0831.2012 .00088 . x$

Glenna L, Brandl B, and Jones K. 2015. International political economy of agricultural research and development. In Handbook of international political economy of agriculture and food. Edited by A Bonanno and L Busch. Edward Elgar Publishing Limited, Northampton, Massachusetts. pp. 322-343.

Goetz SJ. 1992. A selectivity model of household food marketing behavior in sub-Saharan Africa. American Journal of Agricultural Economics, 74(2): 444-452. DOI: 10.2307/1242498

Graves A, Matthews R, and Waldie K. 2004. Low external input technologies for livelihood improvement in subsistence agriculture. Advances in Agronomy, 82: 473-555. DOI: 10.1016/s0065-2113(03) $82007-2$

Harris D, and Orr A. 2014. Is rainfed agriculture really a pathway from poverty? Agricultural Systems, 123(1): 84-96. DOI: 10.1016/j.agsy.2013.09.005

Independent Evaluation Group. 2007. World Bank assistance to agriculture in sub-Saharan Africa: an IEG review. The International Bank for Reconstruction and Development, Washington, D.C.

International Assessment of Agricultural Knowledge, Science, and Technology for Development (IAASTD). 2009. Agriculture at a crossroads: global report. Island Press, Washington, D.C.

Isaacs KB, Snapp SS, Chung K, and Waldman KB. 2016. Assessing the value of diverse cropping systems under a new agricultural policy environment in Rwanda. Food Security, 8: 491-506. DOI: $10.1007 / s 12571-016-0582-x$

Jones AD, Shrinivas A, and Bezner-Kerr R. 2014. Farm production diversity is associated with greater household dietary diversity in Malawi: findings from nationally representative data. Food Policy, 46: 1-12. DOI: 10.1016/j.foodpol.2014.02.001

Kaufman F. 2009. Let them eat cash: can Bill Gates turn hunger into profit? Harper's Magazine, June. pp. 51-59.

Krugman P. 2007. The conscience of a liberal. WW Norton \& Company, New York, New York. 
Kydd JG. 2009. A new institutional economic analysis of the state and agriculture in sub-Saharan Africa. In Institutional economics perspectives on African agricultural development. Edited by JF Kirsten, A Dorward, C Poulton, and N Vink. International Food Policy Research Institute, Washington, D.C. pp. 43-460.

Maxwell D, Ahiadeke C, Levin C, Armar-Klemesu M, Zakariah S, and Lamptey GM. 1999. Alternative food-security indicators: revisiting the frequency and severity of 'coping strategies'. Food Policy, 24: 411-429. DOI: 10.1016/S0306-9192(99)00051-2

Maxwell D, Caldwell R, and Langworthy M. 2008. Measuring food insecurity: can an indicator based on localized coping behaviors be used to compare across contexts? Food Policy, 33: 533-540. DOI: 10.1016/j.foodpol.2008.02.004

Mazoyer M, and Roudart L. 2006. A history of world agriculture: from the neolithic age to the current crisis. The Monthly Review Press, New York, New York.

McMichael P. 2008. Development and social change: a global perspective. Pine Forge Press, Los Angeles, California.

Moseley WG, Carney J, and Becker L. 2010. Neoliberal policy, rural livelihoods, and urban food security in West Africa: a comparative study of The Gambia, Côte d'Ivoire, and Mali. Proceedings of the National Academy of Sciences of the United States of America, 107(13): 5774-5779. PMID: 20339079 DOI: 10.1073/pnas.0905717107

National Academy of Sciences (NAS) Committee on Genetically Engineered Crops. 2016. Genetically engineered crops: experiences and prospects. The National Academies Press, Washington, D.C.

Nyantakyi-Frimpong H, and Bezner Kerr R. 2015. A political ecology of high-input agriculture in northern Ghana. African Geographical Review, 34(1): 13-35. DOI: 10.1080/19376812. 2014.929971

Peet R, and Hartwick E. 2015. Theories of development: contentions, arguments, alternatives. Guilford Press, New York, New York.

Pretty JN. 1997. The sustainable intensification of agriculture. Natural Resources Forum, 21(4): 247-256. DOI: 10.1111/j.1477-8947.1997.tb00699.x

Quaye W. 2008. Food security situation in northern Ghana, coping strategies and related constraints. African Journal of Agricultural Research, 3(5): 334-342.

Raudenbush SW, and Bryk AS. 2002. Hierarchical linear models: applications and data analysis methods. Sage, Thousand Oaks, California.

Riisgaard L, Fibla AME, and Ponte S. 2010. Evaluation study: gender and value chain development. The Danish Institute for International Studies and the Ministry of Foreign Affairs of Denmark, Copenhagen, Denmark.

Smale M, Byerlee D, and Jayne T. 2011. Maize revolutions in sub-Saharan Africa. Policy Research Working Paper 5659. The World Bank, Washington, D.C.

Stokstad E. 2008. Dueling visions for a hungry world. Science, 319: 1474-1476. PMID: 18339914 DOI: $10.1126 /$ science.319.5869.1474 
Stubbs P. 2003. International non-state actors and social development policy. Global Social Policy, 3(3): 319-348. DOI: 10.1177/14680181030033003

Terdoo F, and Feola G. 2016. The vulnerability of rice value chains in sub-Saharan Africa: a review. Climate, 4(3): 47-62. DOI: 10.3390/cli4030047

Tripp R. 2016. Self-sufficient agriculture: labour and knowledge in small-scale farming. Earthscan, London, England.

United States Agency for International Development (USAID). 2009. Global food security response case study: Ghana. Micro Report \#156. USAID, Washington, D.C. [online]: Available from microlinks.org/sites/microlinks/files/resource/files/GFSR_Ghana_Rice_VC_Analysis.pdf.

van den Berg H, and Jiggins J. 2007. Investing in farmers-the impacts of farmer field schools in relation to integrated pest management. World Development, 35(4): 663-686. DOI: 10.1016/j. worlddev.2006.05.004

van der Ploeg JD. 2014. Peasant-driven agricultural growth and food sovereignty. The Journal of Peasant Studies, 41(6): 999-1030. DOI: 10.1080/03066150.2013.876997

Vanloqueren G, and Baret PV. 2009. How agricultural research systems shape a technological regime that develops genetic engineering but locks out agroecological innovations. Research Policy, 38(6): 971-983. DOI: 10.1016/j.respol.2009.02.008

Welsh R, and Glenna L. 2006. Considering the role of the university in conducting research on agribiotechnologies. Social Studies of Science, 36(6): 929-942. DOI: 10.1177/0306312706060062

Wiggins S. 2000. Interpreting changes from the 1970s to the 1990s in African agriculture through village studies. World Development, 28(4): 631-662. DOI: 10.1016/S0305-750X(99)00153-9

Winarto YT. 2004. The evolutionary changes in rice-crop farming: integrated pest management in Indonesia, Cambodia, and Vietnam. Japanese Journal of Southeast Asian Studies, 42(3): 241-272.

Woods N. 2006. The globalizers: the IMF, the World Bank, and their borrowers. Cornell University Press, Ithaca, New York.

Wright BD. 2012. Grand missions of agricultural innovation. Research Policy, 41(10): 1716-1728. DOI: $10.1016 /$ j.respol.2012.04.021 